\title{
Peningkatan Kualitas Air Gambut Menggunakan Metode Elektrokoagulasi dengan Penambahan Garam
}

\author{
Flisia Elsa Lavianiga*, Nurhasanah, Boni P. Lapanporo
}

\author{
aProdi Fisika, FMIPA Universitas Tanjungpura, Jalan Prof. Dr. Hadari Nawawi, Pontianak, Indonesia \\ *Email : flisiaelsa@gmail.com
}

Abstrak

Telah dilakukan penelitian tentang peningkatan kualitas air tanah gambut menggunakan metode elektrokoagulasi dengan penambahan garam. Penelitian ini bertujuan untuk mengetahui kualitas air gambut setelah melewati proses penjernihan dengan metode elektrokoagulasi. Pengambilan sampel air gambut dilakukan di Jalan Karya, Kabupaten Kubu Raya. Sampel air gambut diambil secara langsung dari sumber air gambut, kemudian diproses menggunakan metode elektrokoagulasi. Dalam penelitian ini digunakan variasi waktu kontak dengan 6 buah plat aluminium sebagai elektroda, dan tegangan yang diberikan oleh power supply sebesar 30 V. Parameter yang diuji meliputi pH, TDS (Total Dissolve Solid), warna, dan kadar besi. Kondisi awal air tanah gambut sebelum melalui metode elektrokoagulasi yaitu, nilai pH sebesar 5, nilai TDS sebesar 39 mg/L, warna pada skala 1021 Pt.Co, dan kadar besi terlarut sebesar 24,92 mg/L. Berdasarkan hasil penelitian yang telah dilakukan, diperoleh nilai yang memenuhi standar baku kualitas air bersih pada waktu kontak 300 menit. Pada variasi ini diperoleh nilai optimum dengan nilai pH sebesar 7, TDS sebesar 99 $\mathrm{mg} / \mathrm{L}$, warna pada skala 0 Pt.Co, dan kadar besi terlarut sebesar $0 \mathrm{mg} / \mathrm{L}$.

Kata Kunci : Metode Elektrokoagulasi, Air Gambut, Garam.

\section{Latar Belakang}

Air merupakan kebutuhan pokok bagi kehidupan manusia, untuk konsumsi dan nonkonsumsi. Menurut Peraturan Menteri Kesehatan Republik Indonesia No.492/MENKES/PER/IV/2010, tentang kualitas air minum yang memenuhi standar persyaratan kesehatan adalah tidak berbau, tidak berwarna, dan tidak berasa [1]. Air bersih adalah air sehat yang layak dikonsumsi dan digunakan untuk kebutuhan sehari-hari [2]. Menurut Azwar (1990), air bersih yang digunakan sebagai kebutuhan domestik, sebaiknya tidak berwarna, tidak berbau dan jernih. Jika salah satu syarat tidak terpenuhi, maka air tersebut tidak sehat, karena mengandung zat kimia, mineral, dan zat organik terlarut yang dapat mengubah rasa, warna, bau, dan kejernihan air [3].

Kalimantan Barat merupakan dataran rendah, umumnya terdapat banyak air permukaan atau air gambut. Air gambut adalah air permukaan yang banyak ditemukan di daerah lahan gambut atau dataran rendah, yang mengandung kadar besi, zat organik yang tinggi, serta bersifat asam sehingga perlu pengolahan khusus [4].

Beberapa penelitian mengenai pengolahan air gambut antara lain yaitu, pengolahan air secara adsorpsi menggunakan karbon aktif [5]. Salah satunya adalah dengan menggunakan teknologi Clean Chemical Bentone dan Reverse Osmosis, namun teknologi tersebut membutuhkan biaya operasi yang tinggi serta mudahnya terjadi penyumbatan pada selaput membran [6]. Pada umumnya, air gambut diolah menggunakan metode elektrokoagulasi yang merupakan gabungan dari proses elektrokimia dan proses flokulasi-koagulasi [7]. Dalam proses elektrokoagulasi akan terjadi reaksi redoks, di mana logam-logam akan direduksi dan diendapkan di kutub negatif, sedangkan pada elektroda positif akan terjadi reaksi oksidasi [8].

Penelitian terkait elektrokoagulasi sebelumnya telah dilakukan oleh Rasidah dan Nandar. Menurut Rasidah (2017), peningkatan kualitas air gambut menggunakan metode elektrokoagulasi menghasilkan pH sebesar 9, TDS sebesar $108 \mathrm{mg} / \mathrm{L}$, suhu sebesar $30^{\circ} \mathrm{C}$, dan warna pada skala 13 Pt.Co dengan waktu kontak selama 420 menit dan tegangan $30 \mathrm{~V}$, pada penggunaan 6 plat aluminium [9]. Suswanto (2017), menyisihkan Fe sebesar 88,43\%, warna 92,71\%, dan kekeruhan sebesar 91,30\% dengan metode elektrokoagulasi dan penambahan $\mathrm{NaCl}$ (Natrium Klorida) dengan waktu kontak selama 120 menit pada penggunaan 3 pasang plat aluminium dengan tengangan $12 \mathrm{~V}$ [10].

Pada penelitian ini dilakukan peningkatan kualitas air gambut menggunakan metode elektrokoagulasi dengan penambahan garam. Alat elektrokoagulasi terdiri dari plat aluminium (Al) 
sebanyak 6 sebagai elektroda, tegangan $30 \mathrm{~V}$, variasi waktu kontak 120 menit, 180 menit, 240 menit, dan 300 menit. Proses ini bertujuan untuk meningkatkan kualitas air gambut pada parameter warna, pH, TDS (Total Dissolved Solids), dan kadar besi $(\mathrm{Fe})$.

\section{Metodologi}

Alat-alat yang digunakan pada penelitian yaitu, plat Al 6 keping, voltmeter, amperemeter, stopwatch, power supply, jepit buaya (jack), kabel, dan wadah. Bahan yang digunakan pada penelitian adalah air tanah gambut yang diambil dari Jalan Karya, Kabupaten Kubu Raya dan garam merk Bentul sebanyak 3 gram.

\subsection{Pengambilan Sampel Air}

Jenis sampel yang digunakan pada pelaksanaan penelitian ini adalah sampel sesaat (grab sample), yaitu sampel yang diambil secara langsung pada badan air yang akan dipantau. Sampel air gambut diambil sebanyak $1 \mathrm{~L}$, kemudian sampel disimpan di media botol kaca.

\subsection{Pembuatan Media Elektrokoagulasi}

Proses perancangan media elektrokoagulasi diawali dengan pembuatan sketsa. 6 plat $\mathrm{Al}$ berukuran $10 \mathrm{~cm}$ x $10 \mathrm{~cm}$ disusun secara paralel. Skema dan rangkaian peralatan elektrokoagulasi dapat dilihat pada Gambar 1.

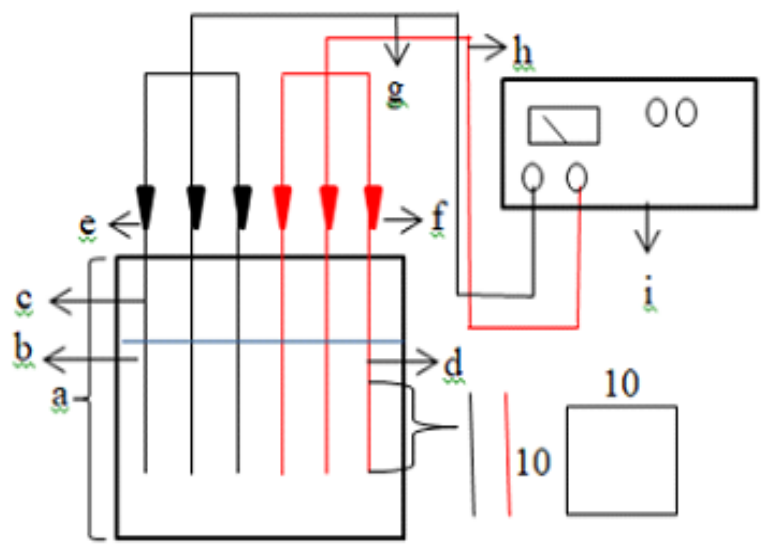

Gambar 1. Skema rangkaian alat metode elektrokoagulasi

Keterangan :

a. Wadah penampung $(21 \times 13 \times 14) \mathrm{cm}$

b. Air

c. Plat aluminum sebagai anoda $(10 \times 10) \mathrm{cm}$

d. Plat aluminium sebagai katoda $(10 \times 10) \mathrm{cm}$

e. Jepit buaya anoda (jack)

f. Jepit buaya katoda (jack) g. Kabel penghantar arus anoda

h. Kabel penghantar arus katoda

i. Power supply

Rangkaian media elektrokoagulasi terdiri dari 6 keping plat alauminium sebagai elektroda, 3 pasang jack atau jepit buaya, kabel, power supply, wadah penampung, dirancang sesuai dengan Gambar 2 sebagai berikut.

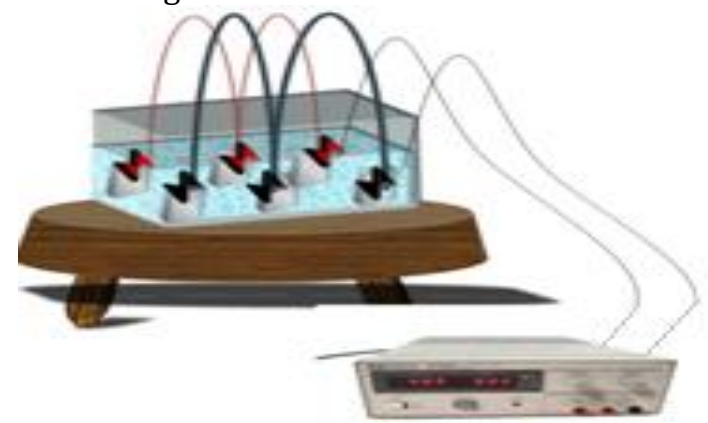

Gambar 2. Rancangan rangkaian alat metode elektrokoagulasi

\subsection{Tahapan Penelitian}

Pada proses pengujian terhadap sampel air gambut sebelum melalui proses elektrokoagulasi, terlebih dahulu dilakukan analisis karakteristik berdasarkan parameter pH, TDS (Total Dissolved Solids), warna, dan kadar besi (Fe). Hal ini bertujuan untuk mengetahui kondisi awal dari sampel air gambut tersebut. Kemudian dilakukan proses peningkatan kualitas air gambut mengggunakan metode elektrokoagulasi dengan penambahan garam. Langkah awal yang dilakukan adalah menambahkan garam sebanyak 3 gram ke dalam air gambut sebanyak 1 liter. Penelitian dilanjutkan dengan mengoperasikan alat elektrokoagulasi yang terdiri dari 6 plat elektroda, menggunakan tegangan sebesar $30 \mathrm{~V}$ selama 120 menit. Setelah melalui proses elektrokoagulasi, sampel air gambut tersebut diuji karakteristiknya berdasarkan parameter $\mathrm{pH}$, TDS (Total Dissolved Solids), warna, dan kadar besi. Percobaan tersebut diulangi untuk variasi waktu 180, 240, dan 300 menit.

\subsection{Analisis}

Untuk mengetahui peningkatan kualitas sampel air gambut sebelum dan setelah melalui proses elektrokoagulasi, dilakukan analisis kuantitatif. Analisa kuantitatif sampel air gambut dilakukan dengan cara membandingkan sampel air gambut hasil elektrokoagulasi terhadap nilai standar baku muku kualitas air bersih yang telah ditetapkan oleh Peraturan Menteri Kesehatan No.32 Tahun 2017 [11]. 


\section{Hasil dan Pembahasan}

3.1 Alat Elektrokoagulasi

Spesifikasi dari alat elektrokoagulasi ini terdiri dari alat utama berupa power supply yang berfungsi sebagai penghantar arus listrik ke komponen yang telah disambungkan. Arus listrik yang dihasilkan merupakan arus listrik AC yang diubah menjadi arus DC. Wadah air gambut memiliki kapasitas sebanyak 1 liter yang akan ditambahkan garam sebanyak 3 gram. Komponen dari wadah terdiri dari 6 buah plat aluminium sebagai elektroda dengan panjang dan lebar $10 \mathrm{x}$ $10 \mathrm{~cm}$ yang dihubungkan dengan jepit buaya. Jepit buaya dihubungkan dengan sebuah kabel sepanjang $30 \mathrm{~cm}$. Ujung kabel pada setiap pasang elektroda dihubungkan dengan power supply.

\subsection{Air Gambut}

Air gambut yang digunakan dalam penelitian ini berasal dari Jalan Karya, Kabupaten Kubu Raya. Pada sampel air gambut, terlebih dahulu dilakukan analisis karekteristik berdasarkan parameter pH, TDS (Total Dissolved Solids), warna dan kadar besi (Fe) yang bertujuan untuk mengetahui kualitas air gambut yang akan diolah. Hasil uji karakteristik air gambut ditunjukkan pada tabel 1 sebagai berikut:

Tabel 1. Hasil Uji Karakteristik Air Gambut

\begin{tabular}{|c|c|c|c|c|}
\hline Parameter & Satuan & Nilai & $\begin{array}{l}\text { Standar } \\
\text { Baku }\end{array}$ & Kualitas \\
\hline $\mathrm{pH}$ & - & 5 & $\begin{array}{l}6,5- \\
8,5\end{array}$ & $\begin{array}{l}\text { Tidak } \\
\text { Layak }\end{array}$ \\
\hline Warna & Pt.Co & 1021 & 50 & $\begin{array}{l}\text { Tidak } \\
\text { Layak }\end{array}$ \\
\hline $\begin{array}{l}\text { Kadar } \\
\text { Besi }\end{array}$ & $\mathrm{mg} / \mathrm{L}$ & 24,19 & 1 & $\begin{array}{l}\text { Tidak } \\
\text { Layak }\end{array}$ \\
\hline TDS & $\mathrm{mg} / \mathrm{L}$ & 39 & 1000 & Layak \\
\hline
\end{tabular}

Tabel 1 menunjukkan hasil uji karakterisitkk air gambut berdasarkan parameter $\mathrm{pH}$, kadar besi dan warna. Kondisi air tersebut tidak memenuhi standar baku mutu yang telah ditetapkan Peraturann Menteri Kesehatan Republik Indonesia Nomor 32 Tahun 2017. Sedangkan pada parameter TDS telah memenuhi standar baku mutu kualitas air bersih, namun masih terlarut sedikit zat organik.

\subsection{Garam Terlarut Setelah Melalui Proses Elektrokoagulasi}

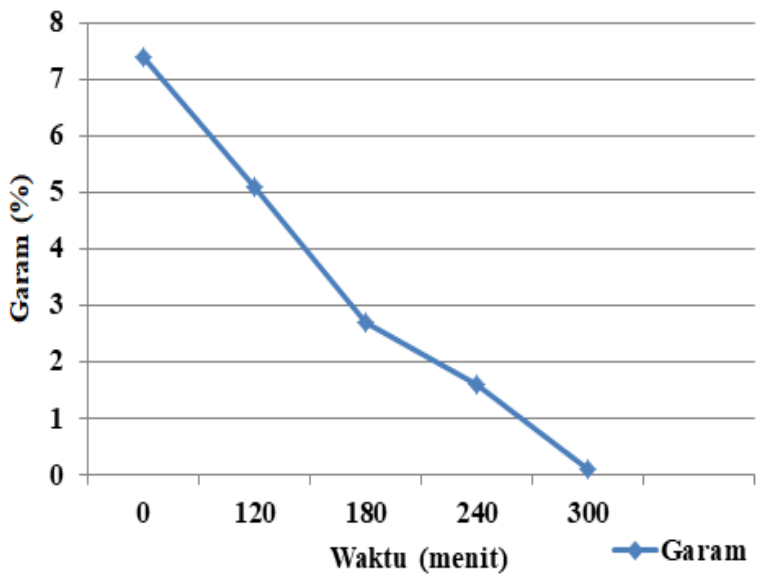

Gambar 3. Efek perubahan garam terlarut pada penambahan waktu kontak.

Gambar 3 menunjukkan kondisi nilai garam terlarut pada air gambut setelah melalui proses elektrokoagulasi. Kondisi garam pada sampel air gambut setelah waktu kontak selama 120 menit sebesar 5,1\%. Kemudian garam terlarut pada waktu kontak 300 menit sebesar 0,11\%. Hasil tersebut menunjukkan adanya pengaruh variasi waktu kontak terhadap garam terlarut, karena semakin lama waktu kontak yang diberikan, semakin kecil konsentrasi garam terlarut dan flokflok akan menggumpal di sekitar elektroda.

\subsection{Parameter $\mathrm{pH}$}

Hasil perubahan parameter $\mathrm{pH}$ air gambut seiring dengan penambahan waktu kontak setelah melalui proses elektrokoagulasi dapat dilihat pada Gambar 4.

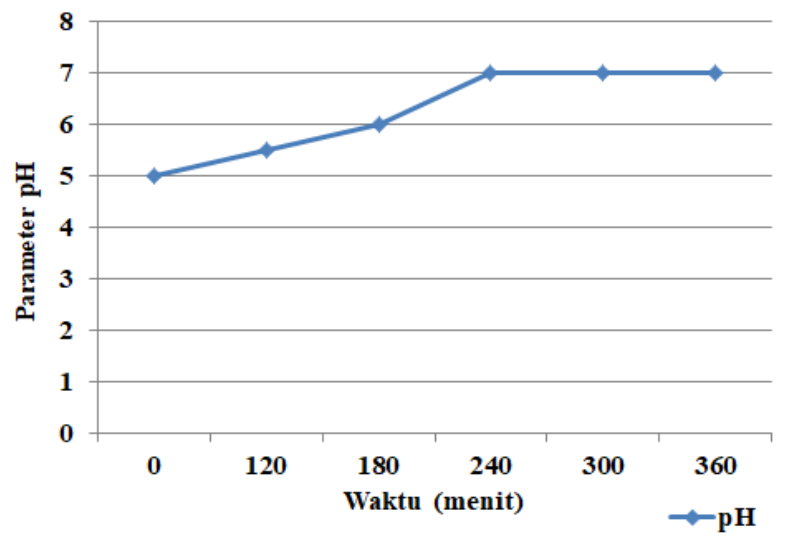

Gambar 4. Pengaruh perubahan parameter $\mathrm{pH}$ terhadap penambahan waktu kontak. 
Gambar 4 menunjukkan nilai $\mathrm{pH}$ pada air gambut setelah melalui proses elektrokoagulasi dengan nilai rentang 5,5 - 7. Kondisi pH air gambut sebesar 7 dalam kategori normal dan memenuhi standar baku mutu kualitas air bersih pada variasi waktu kontak 240, 300, dan 360 menit. Kenaikan pH disebabkan oleh $\mathrm{CO}_{2}$ terlarut yang terlepas dari air gambut dan menjadi gelembung $\mathrm{H}_{2}$ sehingga menyebabkan $\mathrm{pH}$ meningkat [12].

\subsection{Parameter TDS}

Hasil perubahan parameter TDS air gambut seiring dengan penambahan waktu kontak setelah melalui proses elektrokoagulasi dapat dilihat pada Gambar 5.

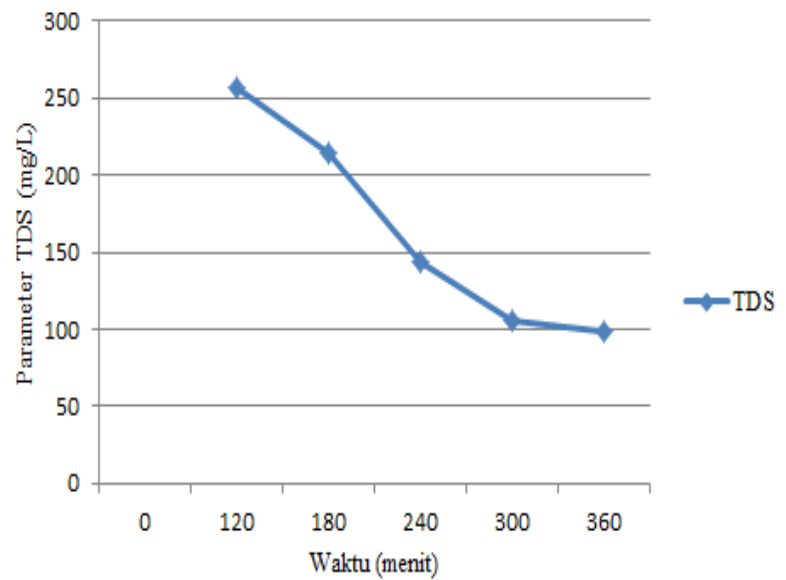

Gambar 5 Pengaruh perubahan parameter TDS terhadap penambahan waktu kontak.

Gambar 5 menunjukkan nilai TDS pada air gambut setelah melalui proses elektrokoagulasi tergolong rendah pada variasi waktu kontak 360 menit dengan nilai sebesar $99 \mathrm{mg} / \mathrm{L}$. Ditunjukkan bahwa parameter TDS pada waktu kontak 120, 180, 240 dan 300 menit telah memenuhi standar baku mutu kualitas air bersih. Nilai TDS tersebut cenderung rendah karena semakin lama waktu kontak yang diberikan selama proses elektrokoagulasi, dapat mengurangi jumlah zat organik dan anorganik yang terlarut dalam sampel air gambut.

Pada sampel air gambut selama proses elektrokoagulasi, terlebih dahulu dilarutkan garam sebanyak 3 gram. Elektrolit garam tersebut akan mengoksidasi padatan terlarut dalam sampel air gambut dan meningkatkan efisiensi dari reaktor elektrokoagulasi (13). Berikut mekanisme reaksi $\mathrm{NaCl}$ selama proses elektrokoagulasi.
Reaksi awal :

$$
\begin{aligned}
& \mathrm{NaCl} \rightarrow \mathrm{Na}^{+}+\mathrm{Cl}^{-} \\
& \mathrm{NaCl}+\mathrm{H}_{2} \mathrm{O} \rightarrow \mathrm{Na}+\mathrm{Cl}+\mathrm{H}_{2} \mathrm{O} \\
& \mathrm{Anoda} \\
& \mathrm{Al}^{3+}+3 \mathrm{H}_{2} \mathrm{O}+3 \mathrm{Cl}^{-} \rightarrow \mathrm{Al}(\mathrm{OH})_{3}+ \\
& 3 \mathrm{HCl}+3 \mathrm{e} \\
& \mathrm{Katoda} \\
& 2 \mathrm{Fe}(\mathrm{OH})_{2}+2 \mathrm{Na}+2 \mathrm{e} \rightarrow 2 \mathrm{Fe}+ \\
& 2 \mathrm{NaOH}+\mathrm{H}_{2} \\
& \mathrm{Al}^{3+}+3 \mathrm{H}_{2} \mathrm{O}+3 \mathrm{Cl} \rightarrow \mathrm{Al}(\mathrm{OH})_{3}+ \\
& 3 \mathrm{HCl}+3 \mathrm{e}
\end{aligned}
$$

\subsection{Parameter Warna}

Hasil perubahan parameter warna air gambut seiring dengan penambahan waktu kontak setelah melalui proses elektrokoagulasi dapat dilihat pada Gambar 6.

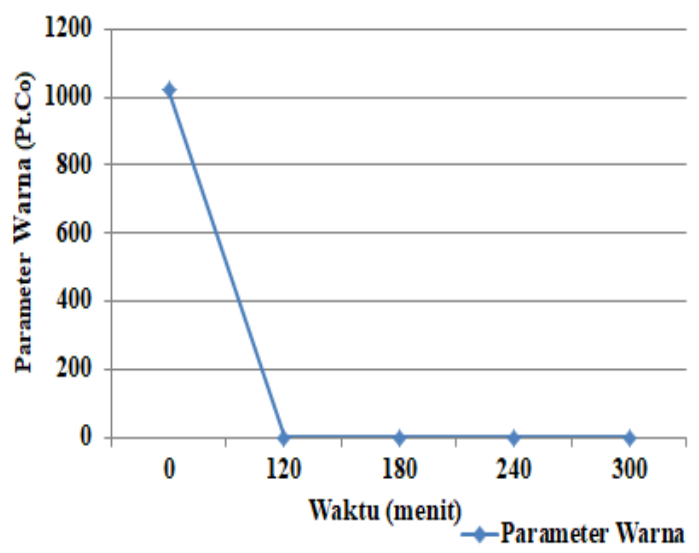

Gambar 6. Pengaruh perubahan parameter warna terhadap penambahan waktu kontak.

Gambar 6 menunjukkan kondisi parameter warna setelah melalui proses elektrokoagulasi. Pada variasi waktu kontak 120, 180, 240, dan 300 menit menghasilkan konsentrasi warna sebesar 0 Pt.Co dan telah memenuhi standar baku mutu kualitas air bersih. Hal ini menunjukkan bahwa air gambut setelah proses elektrokoagulasi berwarna jernih (tidak berwarna). Penurunan parameter warna pada air gambut disebabkan oleh proses dekolorisasi akibat adanya proses koagulasi tersebut (14).

\subsection{Parameter Kadar Besi}

Hasil perubahan parameter kadar besi air gambut seiring dengan penambahan waktu kontak setelah melalui proses elektrokoagulasi dapat dilihat pada Gambar 7. 


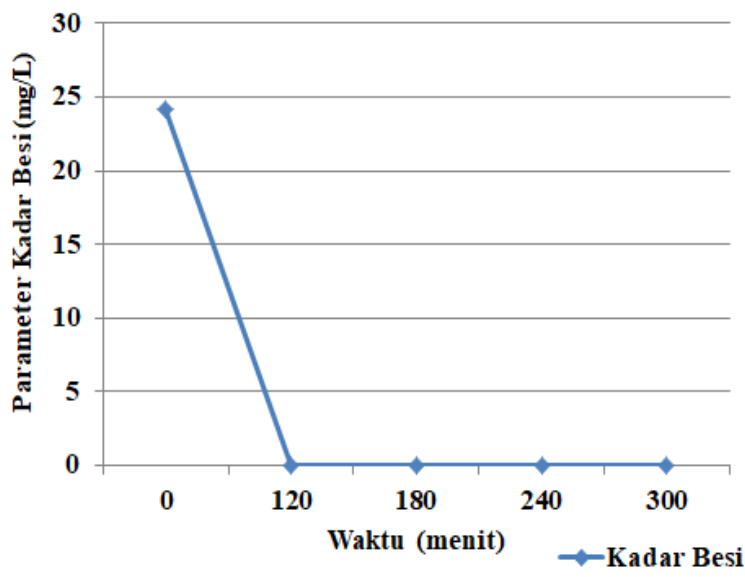

Gambar 7. Pengaruh perubahan parameter kadar besi terhadap penambahan waktu kontak.

Gambar 7 menunjukkan nilai tingkat perubahan kadar besi terlarut pada air gambut setelah melalui proses elektrokoagulasi pada variasi waktu kontak 120, 180, 240, dan 300 menit menghasilkan kadar besi terlarut sebesar 0 $\mathrm{mg} / \mathrm{L}$ dan telah memenuhi standar baku mutu kualitas air bersih. Berdasarkan hasil pengujian sampel air gambut setelah melalui proses elektrokoagulasi dengan penambahan garam sebanyak 3 gram, dapat dinyatakan bahwa tidak terlarut logam besi. Berikut mekanisme reaksi $\mathrm{NaCl}$ terhadap penyisihan kadar besi selama proses elektrokoagulasi

$$
\begin{aligned}
& \text { Anoda } \\
& \mathrm{Cl}^{-} \rightarrow \mathrm{Cl}_{2}+2 \mathrm{e}^{-} \\
& \mathrm{Cl}_{2}+\mathrm{H}_{2} \mathrm{O} \rightarrow \mathrm{HOCl}+\mathrm{H}^{+} \mathrm{Cl}^{-} \\
& \mathrm{HOCl} \rightarrow \mathrm{H}^{+}+\mathrm{OCl}^{-} \\
& \mathrm{Fe}^{2+}+2 \mathrm{Cl}^{-} \rightarrow \mathrm{FeCl}_{2} \\
& \mathrm{FeCl}_{2}+3 \mathrm{OH}^{-} \rightarrow \mathrm{Fe}(\mathrm{OH})_{3}(\mathrm{~s})+2 \mathrm{Cl}^{-}
\end{aligned}
$$

Selama proses elektrokoagulasi, penyisihan kadar besi terlarut terjadi ketika semakin banyaknya ion $\mathrm{Al}^{3+}$ yang dihasilkan pada anoda dan membentuk flok $\mathrm{Al}(\mathrm{OH})_{3}$ yang berperan sebagai koagulan. Kemudian flok $\mathrm{Al}(\mathrm{OH})_{3}$ tersebut dapat mengikat senyawa organik dan logamlogam yang terkandung dalam air (15).

\section{Kesimpulan}

Berdasarkan hasil metode elektrokoagulasi yang telah dilakukan pada air gambut dengan penambahan garam, diketahui bahwa pada parameter $\mathrm{pH}$ telah memenuhi kualitas air bersih pada waktu kontak selama 240 menit dan untuk parameter TDS pada waktu kontak selama 360 menit. Parameter warna dan kadar besi telah memenuhi kualitas air bersih pada waktu kontak selama 120 menit.

\section{Daftar Pustaka}

[1] Peraturan Menteri Kesehatan Republik Indonesia No. 492 / MENKES / PER / IV / 2010 Tentang Persyaratan Kualitas Air Minum, 2010.

[2] Kurniasih, Gunawan, R. Panggabean. Aplikasi Metode Elektrokoagulasi Terhadap Penurunan Kadar Ion Logam Fe, Mn, Kekeruhan, Warna Pada Pengolahan Air Gambut Secara Batch, 2016.

[3] Azwar, Pengantar Ilmu Kesehatan Lingkungan, Yayasan Mutiara Sumber Widya, Jakarta, 1990.

[4] Nainggolan, Pengolahan Air Gambut dan Sungai dengan Sederhana, USU Press, Medan, 2011.

[5] Suhendra, Winda A, Ellys M S. Uji Kinerja Alat Penyerap Warna dan pH Air Gambut Menggunakan Arang Aktif Tempurung Kelapa, Jurnal POSITRON, 6(1), 35-39, 2016.

[6] Naswir. Kajian Pemanfaatan Air Gambut Untuk Air Minum Rumah Tangga (Penggunaan Teknologi Clean Chemical Bentone), Badan Penelitian dan Pengembangan, Jambi, 2009.

[7] Irawan D, Arifin Z, Maulidya E, Proses Penurunan Zat Warna dalam Limbah Cair Industri Sarung Samarinda dengan Metode Elektrokoagulasi, JRTI, 6(11), 31-36, 2012.

[8] Yulianto A, Hakim L, Purwaningsih. Pengolahan Limbah Cair Industri Batik Pada Skala Laboratorium Dengan Menggunakan Metode Elektrokoagulasi, Jurnal Teknik Lingkungan, 2009.

[9] Rasidah, Lapanporo B. P, Nurhasanah, Peningkatan Kualitas Air Tanah Gambut dengan Menggunakan Metode Elektrokoagulasi, Jurnal PRISMA Fisika 5(2), 77-82, 2017.

[10] Suswanto N, Penyisihan Fe, Warna, Dan Kekeruhan Pada Air Gambut Menggunakan 
Metode Elektrokoagulasi, Jurnal Teknik Lingkungan, 6(2), 2017.

[11] Peraturan Menteri Kesehatan Republik Indonesia No. 32 Tentang Persyaratan Kualitas Air Minum, 2010.

[12] Hermida L, Suhendra, Treatment of Rubber Factory Wastewater by Electrocoagulation Process Using Iron Electrodes,Fakultas Teknik, Universitas Lampung, 2006.

[13] Kuokkanen, V., Kuokkanen, T., Rämö, J., Lassi, U. Electrocoagulation treatment of peat bog drainage water containing humic substances. Water Research Unit of Sustainble Chemistry, Univercity of Oulu, Finland, 79, 79-87, 2015.

[14] Darmawan A, Suhartana, Kristinawati L, Koagulasi Pewarna Indigo Karmina dengan Metode Elektrolisis menggunakan Anoda Seng, Jurnal Teknik Lingkungan, IX, 2006.

[15] Retna, Wenny D, Studi Penurunan Kromium dan Nikel Pada Pengolahan Limbah Elektroplating Dengan Metode Elektrokoagulasi, Jurnal Teknik Lingkungan, 2013. 